\title{
Ekofilozofia i środowisko przyrodnicze
}

Ekofilozofia - zamiennie używa się także nazw: filozofia ekologii, filozofia ekologiczna, ekologia humanistyczna, enwironmentalizm, ekologizm niekiedy praktyczna filozofia przyrody i in. - jest obecnie ujmowana i uprawiana w Polsce na dwa sposoby. Dla jednych - i takie podejście dominuje, wśród uczestników różnych ruchów i stowarzyszeń ekologicznych oraz w środkach masowego przekazu - ekofilozofię stanowią luźne, ogólne rozważania dotyczące spraw egzystencjalnie i moralnie ważnych a będących rezultatem kłopotów człowieka (społeczeństwa, zglobalizowanej ludzkości) ze środowiskiem przyrodniczym. Tak uprawiana wiąże się zwykle z postulatami i programami ochrony środowiska stając się teoretyczną podstawa dla ideologii różnych pozarządowych organizacji ochrony środowiska i partii „zielonych" (i wtedy utożsamia się ją z ekologizmem jako określoną - choć różnie aksjologicznie ukierunkowaną i zniuansowaną - „zieloną", ochroniarską ideologią). Inni, mówiąc o ekofilozofii, mają na myśli poddane określonym, przyjętym w środowiskach akademickich rygorom, podejmowanie i poszukiwanie rozwiązań problemów filozoficznych dotyczących relacji i interakcji zachodzących między człowiekiem a przyrodą. Tak rozumiana staje się filozofią w sensie zinstytucjonalizowanym, akademickim.

Filozofia akademicka - jak wiadomo - też uprawiana jest różnie, zawsze jednak poddawana jest określonym przez środowisko rygorom, jest jakoś intersubiektywnie artykułowana, teoretycznie ujęta i metodologicznie uporządkowana. Krótko to ujmując można powiedzieć, iż jest dyskursywnie uporządkowanym, zobiektywizowanym rezultatem ludzkiego dążenia do istotowego, maksymalnie ogólnego i całościowego zrozumienia świata, człowieka i egzystencjalnie ważnych jego relacji i interakcji z tymże światem. Zrozumienia, które (i to stanowi o swoistości, odrębności filozofii) jednocześnie jest określaniem (nazywaniem, ujmowaniem i nadawaniem znaczeń, lokowaniem w kontekstach), objaśnianiem (wskazywaniem uniwersalnych, koniecznych praw i zasad stanowiących rację istnienia i determinujących istotę przedmiotu refleksji) i wartościującym przeżywaniem świata i własnego $\mathrm{w}$ nim istnienia (egzystencjalnie ważnym doświadczeniem rzeczywistości, ekspresją świadomości bycia i współuczestnictwa w byciu, doświadczeniem orientującym i organizującym poznawczą i praktyczną aktywność człowieka). 
Powstając, ekofilozofia była - i dla wielu nadal jest - emocjonalnie nasyconym oraz treściowo i aksjologicznie jednoznacznie określonym filozofowaniem dotyczącym ochrony środowiska, przyrody i naturalnych powiązań człowieka z przyrodą: już sama nazwa wyraźnie określała kierunek, treści i sposób filozoficznego zaangażowania i była utożsamiana z jednym, radykalnie „zielonym” sposobem pojmowania świata i miejsca człowieka w nim. Z biegiem lat zaczęły ujawniać się różnice podejść, odmienność stanowisk i zniuanosowanie wartościowań, analizowana problematyka ulega pogłębieniu i poszerzeniu, stopniowo kwestie te zaczęły być włączane w obieg filozofii zawodowej.

$\mathrm{Na}$ VI Polskim Zjeździe Filozoficznym w Toruniu (w 1995 r.) utworzona została sekcja ekofilozofii i bioetyki. W trakcie obrad tej sekcji zaproponowano, by terminy ekofilozofia i filozofia ekologii traktować jako synonimy oznaczające kształtujące się nowe pole problemowe filozoficznych dociekań. Wskazywano, iż na gruncie tak ujmowanej - zakresowo - ekofilozofii możliwe są, i faktycznie mają miejsce, różne poglądy i stanowiska dotyczące rozumienia i wartościowania współzależności między człowiekiem (społeczeństwem) i przyrodą; poglądy będące wyrazem przyjętych założeń ontologicznych, epistemologicznych i aksjologicznych a także, indywidualnych doświadczeń i preferencji ${ }^{1}$. Przyjmując ten punkt widzenia należy uznać, ż w obrębie tak rozumianej ekofilozofii możliwe są zarówno koncepcje jednoznacznie proekologiczne (w pozytywnie wartościującym rozumieniu słowa ekologiczny - jako zgodny z naturą, przyjazny przyrodzie itp.) jak i anty - czy aekologiczne (technokratyczne, skrajnie antropocentryczne).

W ciągu dziesięciu lat, które upłynęły od VI Zjazdu Filozoficznego pojawiły się kolejne, nowe ujęcia ekofilozofii, wzbogacony został zarówno zakres stawianych w niej pytań jak i sformułowano szereg nowych propozycji. Pozostał jednak bałagan terminologiczny - nadal brak jest zgody, co do nazwy tej sfery filozofowania i funkcjonuje tu wiele różnych określeń ${ }^{2}$ - i można odnieść wrażenie, iż status tej sfery filozofowania poddawany jest jeszcze w wątpliwość przez niektórych przedstawicieli filozofii akademickiej.

I dlatego, myślę, potrzebna jest dyskusja o charakterze metafilozoficznym dotycząca ekofilozofii, dyskusja, która pozwoliłaby:

- zdiagnozować aktualny status ekofilozofii, ustalić, co ma się na myśli używając tego terminu i precyzyjniej określić filozoficzność tej sfery rozważań;

- wstępnie - na tyle, na ile to obecnie możliwe - obrysować, wyznaczyć jej pole problemowe;

Por.: Ekofilozofia i bioetyka. Materiały VI Polskiego Zjazdu Filozoficznego, pod red. W. Tyburskiego, Wyd. TOP KURIER, Torun 1996.

2 Por.: J.M. DoŁçGA, Ekofilozofia i nauki środowiskowe na początku XXI wieku, w: „Szkice Humanistyczne", Wyd. OSW, Olsztyn 2005, s. 251-267. 
- określić, analizując faktycznie stosowane sposoby i metody filozofowania w tej sferze, minimum ,akademickiej” poprawności metodologicznej;

- wypracować - przynajmniej dla celów dydaktycznych - propozycję wstępnego standardu rozumienia ekofilozofii.

Zdaję sobie sprawę, że nie jest to łatwe, bowiem już sama natura filozofowania i powszechny nawet wśród zawodowych filozofów brak zgody na to, co jest filozofią i jakie są dopuszczalne czy właściwe metody jej uprawiania sprawia tu wiele kłopotów. A przecież należy tu uwzględnić także dynamiczny charakter zagrożeń i kłopotów człowieka z przyrodą, oraz - w konsekwencji - pojawianie się nowych kwestii filozoficznych z tym związanych.

We wszystkich ujęciach i rozważaniach ekofilozoficznych mówi się o środowisku przyrodniczym bądź naturalnym. Zwykle używa się tych terminów nie precyzując bliżej ich zakresu i znaczenia, zakładają, iż każdy wie jak je rozumieć. Myślę jednak, iż sprawa nie jest tak prosta i oczywista jak się na pozór wydaje i wymaga pewnych wyjaśnień i dopowiedzeń. Już samo pojęcie środowiska rozumiane jest różnie. Jedni utożsamiają je z wszystkim co jest, nie wyróżniając centrum, czy wyodrębnionego podmiotu dla którego to co jest wokół niego, jest środowiskiem. Inni, zdając sobie sprawę, iż środowisko jest zawsze czyimś środowiskiem, utożsamiają je z wszystkim co to coś otacza, z otoczeniem. Tutaj - odwołując się do słowników języka polskiego i poświęconego tym kwestiom studium prof. Adama Kotarbińskiego ${ }^{3}$ - przyjmuję, iż należy odróżnić środowisko od otoczenia. Mówiąc o otoczeniu mamy bowiem zwykle na myśli zbiór przedmiotów, relacji, oddziaływań itp. istniejących wokól "czegoś" (będący w relacji przestrzennej z tym co jest otoczone) i zwykle nie wnikamy (nie interesuje nas to) w charakter, naturę związków między tym „czyms'” a jego otoczeniem. Natomiast środowiskiem nazwiemy "tylko takie otoczenie w którym zachodzq wzajemne uwarunkowania bytu i rozwoju czegoś, co jest otoczone i jego otoczenia"4. Krótko mówiąc: środowisko jest zawsze zrelatywizowane do jakiegoś wyróżnionego podmiotu/przedmiotu i wyodrębnione $\mathrm{z}$ otoczenia ze względu na jakieś konieczne i ważne dla jego istnienia i funkcjonowania zależności i relacje. To zaś o jakim środowisku mówimy (przyrodniczym, kulturowym, społecznym, fizycznym, biologicznym itp.) wyznaczone jest przez będące przedmiotem naszego zainteresowania realne własności, powiązania, współzależności i procesy wyodrębnione z otoczenia ze względu na ich ważność, znaczenie dla wyróżnionego podmiotu/przedmiotu. Koncentrujemy się wtedy na określonym, wybranym rodzaju czy aspekcie współzależności i relacji ze środowiskiem (czy w środowisku),

\footnotetext{
A. Kotarbiński, Zasady tworzenia pojęć i nazw do systemowego kształtowania środowiska IKS, Wydawnictwo Katalogów i Cenników, Warszawa 1977, s. 33-43. Por. też: T. BarTKowski, Ksztaltowanie i ochrona środowiska czlowieka, PWN, Warszawa 1991, s. 47-53.

4 Tamże, s. 42.
} 
zdając sobie zarazem sprawę z tego, że jest on powiązany z innymi wymiarami i własnościami środowiska. I wtedy o tyle je uwzględniamy, o ile są one ważne $\mathrm{z}$ interesującego nas punktu widzenia.

Ekofilozofia koncentruje się na relacjach człowieka ze środowiskiem przyrodniczym. Przyjmuję tu potoczne rozumienie tego terminu, włączając w jego zakres nie tylko ogół naturalnych elementów abiotycznych i biotycznych ukształtowanych w procesie ewolucji biosfery i warunkujących istnienie i funkcjonowanie człowieka jako istoty żywej (gatunku zoologicznego) ale również elementy przyrody przekształcone przez człowieka i zwrotnie nań oddziaływujące (przyroda „uczłowieczona”). Nie używam określenia środowisko naturalne (w sensie: nie tknięte jeszcze ręką ludzką), gdyż takiego na naszej planecie praktycznie już nie ma. Inne środowiska człowieka (aspekty, wymiary jego istnienia i funkcjonowania) o tyle są uwzględniane i analizowane na gruncie ekofilozofii, o ile określają, wpływają na relacje człowieka z przyrodą.

Człowiek - zarówno jako element przyrody jak i transcendujący ją podmiot działania teoretycznego i praktycznego - jest w refleksji ekofilozoficznej ujmowany w czterech zasadniczych wymiarach (choć większość autorów nie dokonuje zwykle tych rozróżnień, mówiąc o człowieku „w ogóle”, bądź też koncentrując się na biologiczno-gatunkowym czy społecznym sposobie ludzkiego istnienia). Po pierwsze, można konfrontować człowieka z przyrodą jako jednostkę, konkretny egzemplarz gatunku homo sapiens z jego biopsychicznymi i społecznymi właściwościami i oddziaływaniami na przyrodę. Po drugie - i najczęściej - ujmuje się człowieka w sensie gatunkowym: w kategoriach biologiczno-ekologiczno-populacyjnych i w tym aspekcie uwzględnia się jego oddziaływanie na naturalne ekosystemy. Docieka się tu zarazem tego, co stanowi o jego specyfice i ,istocie gatunkowej" - biorąc oczywiście pod uwagę także społeczny sposób egzystencji egzemplarzy tego gatunku jako nową jakość ukształtowaną w procesie ewolucji biologicznej. Po trzecie, mówiąc „człowiek” ma się na myśli społeczeństwo - społeczności ludzkie, cywilizacje, wprawdzie żyjące w określonym środowisku przyrodniczym i potrzebujące go dla swojego istnienia, ale dzięki socjo i technosferze ustanawiające własne prawa funkcjonowania w przyrodzie i usiłujące narzucić jej swoje „zasady gry”. I wreszcie, po czwarte - i ten wymiar ludzkiej egzystencji ujawnił się dopiero w drugiej połowie XX w. - czlowiek to „zglobalizowana ludzkość", nowa jakość społeczno-technologicznego, ale przecież bazującego na przyrodzie, życia ludzi. Ludzi, którzy choć wewnętrznie podzieleni i skłóceni, to przecież od siebie zależni: jako całość w skali globalnej tak przekształcają i degradują ziemską biosferę, że stawiają pod znakiem zapytania swe dalsze gatunkowo-społeczne istnienie.

W tym kontekście trzeba zastanowić się nad tym, czym różni się ekofilozofia od poszukiwania racji dla uzasadnień ochrony środowiska (że środowisko trzeba chronić nikt bowiem nie wątpi - spory dotyczą tego w jakim zakresie i jak) oraz 
od rozważań dotyczących filozoficznych konsekwencji (zarówno w ich wymiarze teoretycznym - dla lepszego zrozumienia świata i siebie - jak i w wymiarze praktycznym - dla wytyczania celów działania i postępowania) obecnych kłopotów człowieka ze środowiskiem przyrodniczym. Czy luźne rozważania na te tematy można określić jako ekofilozofię? Myślę, że nie, że po trzydziestu latach podejmowania tej problematyki należy nazwę ekofilozofia zastrzec dla metodologicznie uporządkowanych i świadomych swego przedmiotu teoretycznych rozważań i propozycji. I można już wyznaczyć - przynajmniej z gruba - pole problemowe tej sfery filozofowania, ukazać jej aspiracje i zadania oraz wyodrębnić ją instytucjonalnie.

I chociaż filozofowie zajmujący się tą problematyką koncentrują się na różnych kwestiach i niekiedy odmiennie określają swój przedmiot (a często prezentują przeciwstawne tezy na dany temat), jednakże, myślę, można pokusić się o wyodrębnienie tego co ich łączy i co pozwala mówić o wspólnym przedmiocie dociekań. Jest nim przyroda i człowiek jednocześnie, w ich jedności, współzależnościach i interakcjach rozważanych z punktu widzenia ich istoty, sposobów istnienia i poznania, wartości i wartościowania, kwalifikacji moralnej oraz możliwości ich przewidywania i regulowania w trosce o dobro (istnienie) człowieka i biosfery (bądź vice versa: biosfery i człowieka). Zawarte w nawiasach odwrócenie kolejności członów relacji ukazuje, iż w zależności od przyjętej hierarchii ważności („od - ludzkiej” bądź „od - przyrodniczej”) jedne ujęcia charakteryzować będzie podejście humanistyczne, mniej bądź bardziej antropocentryczne, drugie zaś biocentryczne, holistyczne czy nawet kosmocentryczne. Niezależnie jednak od takiego czy innego "aksjologicznego nachylenia”, dominującym, centralnym przedmiotem dociekań są relacje, interakcje miedzy stanowiącymi jedność elementami. Nie przyroda, biosfera czy środowisko przyrodnicze (i jego ochrona) jako takie czy „samo w sobie” - tym zajmują się nauki przyrodnicze (i sozologia). I nie człowiek - nim w różnych wymiarach zajmuje się wiele nauk o człowieku a pytanie o to „czym i kim jest człowiek?” w różny sposób podejmuje i rozwiązuje antropologia filozoficzna.

W rozważaniach i dociekaniach ekofilozoficznych można wyróżnić kilka zasadniczych obszarów zagadnień konstytuujących jej pole problemowe. Są to:

1. Zagadnienia dotyczące zarówno statusu ontycznego przyrody (biosfery) w procesie współtworzenia i „uczłowieczania” jej przez społeczności ludzkie, jak i pytania o miejsce i sposób istnienia człowieka (jako jednostki, gatunku, społeczeństwa, zglobalizowanej ludzkości) w przyrodzie (biosferze). W obecnej sytuacji ekologicznej poszukuje się więc odpowiedzi na pytanie o to czym i kim jest człowiek w swych relacjach z przyrodą, na ile do niej przynależy i od niej zależy jako wspóttworzący ją gatunek (czym jest) a na ile i w jakim sensie przekracza, transcenduje własną przyrodniczość i biosferę tworząc antroposferę (kim się staje). W tym kontekście szczególnie aktualną staje się kwestia bytowej tożsamości 
biosfery zakwestionowanej w wyniku lawinowego wręcz narastania antropopresji i zmniejszania się bioróżnorodności („szósta katastrofa” w historii życia na Ziemi prowadząca do zmiany kierunku ewolucji biosfery). Dramatycznej wręcz wymowy przybiera pytanie o perspektywy dalszego rozwoju zglobalizowanej ludzkości w warunkach postępującej degradacji środowiska przyrodniczego.

2. Rozważania aksjologiczne dotyczące zarówno samej przyrody i różnych jej elementów (ekosystemów, istot zywych czy nawet przedmiotów i układów nieożywionych), jak i relacji i związków człowieka $z$ nią oraz kwestie etyczne i estetyczne wynikające z komplikowania się współzależności i wzajemnych oddziaływań między człowiekiem a przyrodą. Najczęściej podejmuje się problem aksjologicznych uwarunkowań obecnego kryzysu ekologicznego, analizując funkcjonujące systemy wartości i ich wpływ na traktowanie środowiska przyrodniczego przez ludzi, uznając, iż w leżących u ich podstaw wartościach tkwi źródło konfliktu antroposfery z biosferą.

Przedmiotem filozofowania staje się więc coraz częściej wartościujące traktowanie przyrody oraz techniki i technologii w ich oddziaływaniu na środowisko przyrodnicze. Przestając być czymś oczywistym, trwałym, pewnym i niewyczerpalnym przyroda zaczęła być traktowana jako coś potrzebnego i pożądanego, stała się dobrem. I to nie tylko dobrem ekonomicznie cennym - tym była zawsze dla człowieka - lecz także dobrem rozpatrywanym w kategoriach etycznych, estetycznych, religijnych.

W ścisłym związku i w oparciu o rozstrzygnięcia dokonywane w ramach problematyki "aksjologizacji przyrody” i przetwarzania jej przez człowieka podejmowane są kwestie stosunku człowieka do przyrody w kategoriach dobra i zła moralnego, obowiązku i odpowiedzialności, co wiąże się też zwykle z różnymi propozycjami budowania etyki ekologicznej (środowiskowej).

3. Następny krąg rozważań stanowią analizy dotyczące zakłóceń w funkcjonowaniu czy wręcz załamywanie się dotychczasowych form, sposobów wyrażania się relacji i interakcji między przyrodą i człowiekiem - co powszechnie określa się jako kryzys ekologiczny czy kryzys biosfery. Z filozoficznego punktu widzenia rozważa się przede wszystkim trzy aspekty tych relacji: a) „metafizyczno-egzystencjalny" - dotyczący takiego transcendowania przyrody (ekspresji człowieczeństwa), które pozwoli zachować istnienie i tożsamość człowieka i biosfery (problem dalszych możliwości czy granic realizacji ludzkiego dążenia do „być więcej"); b) cywilizacyjno-społeczny - zakwestionowanie aksjologicznych podstaw dotychczasowego kierunku rozwoju cywilizacyjnego zglobalizowanej ludzkości; c) egzystencjonalno-przyrodniczy - zagrożenie dalszego istnienia człowieka jako gatunku zoologicznego.

Zmierzając do uchwycenia istoty, przyczyn i głównych uwarunkowań tego kryzysu podejmuje się problem sprzeczności między dominującym współcześnie kierunkiem rozwoju cywilizacyjnego a skończonością, ograniczonością Ziemi 
(biosfery) i jej zasobów. Istotną i wymagającą wszechstronnego badania jest tu kwestia niewspółmierności skali, głębi i tempa (ciągłej akceleracji) zmian dokonywanych przez człowieka w przyrodzie z ewolucyjnie ukształtowanymi mechanizmami rekompensowania zakłóceń zachodzących w ekosystemach i biosferze. W tym kontekście rozważa się różne możliwości przezwyciężenia kryzysu i poszukuje wizji społeczeństwa rozwijającego się w zgodzie ze środowiskiem przyrodniczym, koncentrując się przede wszystkim na kwestiach aksjologicznych.

4. Kolejną grupę problemów ekofilozofii, problemów niezmiernie ważnych lecz stosunkowo rzadko podejmowanych i może najmniej kojarzących się z dążeniem do zrozumienia relacji człowieka z przyrodą, stanowią kwestie związane $\mathrm{z}$ analizą różnych form organizacji ładu społecznego, funkcjonujących struktur życia politycznego, działalności gospodarczej, wzorców kultury oraz dominujących w życiu społecznym i sferze polityki ideologii z punktu widzenia ich miejsca i roli we współtworzeniu układu „człowiek (społeczeństwo) - przyroda”. Krótko mówiąc, idzie tu o badanie czynników określających „społeczne konstytuowanie” przyrody. A także - z drugiej strony rzecz ujmując - wpływu przemian zachodzących w biosferze na procesy społeczne, formy, struktury i treści życia społecznego, przemiany gospodarcze itp. Zagadnienia te rozpatruje się w ścisłym związku z problematyką aksjologiczną i „kryzysologiczną”, jednakże punkt ciężkości położony jest tu na społeczne, polityczne, ideologiczne i ekonomiczne uwarunkowania i konsekwencje interakcji między człowiekiem a biosferą. Szczególnie ważne są tu analizy podstaw dotychczasowej filozofii gospodarowania przyrodą i poszukiwanie wspólnego mianownika dla integracji kryteriów ekonomicznych i wymogów (kryteriów) przyrodniczych w działalności gospodarczej i - w konsekwencji - wspólnej miary efektywności. Wiąże się to z koniecznością rewizji, a może i porzucenia, tradycyjnego paradygmatu myślenia ekonomicznego oraz poszukiwaniem nowych aksjologicznych uzasadnień dla wyłaniającej się odmiennej teorii gospodarowania - ekonomii ekologicznej, zakładającej konieczność integracji ekonomii i ekologii.

5. Ostatnio coraz częściej podejmowane są także rozważania dotyczące miejsca i roli przyrody $\mathrm{w}$ indywidualnie przeżywanym i wartościowanym egzystencjalnym doświadczeniu świata, problemy „ekologicznego stylu życia”, analizowanie własnego sposobu bycia i postępowania oraz relacji ze środowiskiem przyrodniczym z punktu widzenia ich wpływu na jakość życia, zadowolenie, zdrowie, poczucie szczęścia itp. Rozpatruje się kwestię dążenia do harmonizowania jednostkowego życia z przyrodą w kategoriach sensu i celu życia, źródła zadowolenia i sposobu na samorealizację dowodząc często, że jaźń indywidualna jest związana z całym środowiskiem zaś pełna samorealizacja wymaga „poszerzenia świadomości" - identyfikacji z kolejno rozszerzającymi się kręgami wspólnoty ludzkiej i przyrodniczej. W tym kontekście rozważane są powiązania i zależności między bezinteresowną kontemplacją przyrody, sposobem odżywiania się (odpo- 
wiednią dietą), higieną życia codziennego itp. a jasnością i sposobem myślenia, respektowaniem zasad moralnych w postępowaniu, zadowoleniem i szczęściem. W rozważaniach tych niejednokrotnie nawiązuje się do praktyk religijnych i myśli filozoficznej Dalekiego Wschodu. Tego rodzaju kwestie można by włączyć do sfery prywatnej ego-ekozofi - gdyby nie fakt, że ich treści i rezultaty tych rozważań są publikowane, upowszechniane w środkach masowego przekazu i funkcjonują w świadomości społecznej.

Zaprezentowane tu zagadnienia nie wyczerpują wprawdzie pola problemowego ekofilozofii, można jednak powiedzieć, iż w nim dominują i obrysowują dzisiaj jego zakres. To oczywiste, że jego granice stale się zmieniają w wyniku postępów przyrodoznawstwa, narastających "kłopotów" człowieka z przyrodą i przemian cywilizacyjno-kulturowych i politycznych zachodzących w coraz bardziej globalizującym się świecie. Nie prezentowałem tu formułowanych na gruncie różnych kierunków czy szkół koncepcji, tez i rozstrzygnięć problemów - taką prezentację odkładam na inną okazję. Chodziło mi tu - jak i wcześniej, gdy próbowałem ukazać swoistość przedmiotu ekofilozofii - o wstępne, szkicowe zarysowanie zakresu dominującej problematyki charakterystycznej dla tej nowej sfery filozofowania.

Lektura licznych wypowiedzi i publikacji z zakresu przedstawionej problematyki skłania mnie do sformułowania kilku ogólnych uwag dotyczących obecnego statusu ekofilozofii, tego czym faktycznie jest, jaka być powinna i jak nie należy jej pojmować i uprawiać.

Jest więc ekofilozofia konsekwencją coraz dotkliwiej odczuwanych i przeżywanych - egzystencjalnie ważnych - kłopotów człowieka (społeczeństwa, ludzkości) z przyrodą. Kłopotów przede wszystkim praktycznych, manifestujących się globalnym kryzysem ekologicznym i zwiastujących możliwość doprowadzenia do samozagłady gatunkowej. Także kłopotów teoretycznych, wynikających z zakwestionowania $\mathrm{z}$ końcem XX wieku wielu poglądów i przeświadczeń uznawanych dotąd za oczywiste. Oto zakwestionowane zostały:

- przekonanie o zasadniczej „inności” człowieka, jego wyjątkowości i bytowej autonomii oraz możliwości dowolnego stanowienia, kształtowania sfery swego życia;

- przeświadczenie o wyłączności, monopolu człowieka na posiadanie świadomości i umiejętności myślenia;

- wiara w niewyczerpalność przyrody i jej zasobów, w to, że zawsze będzie dla nas w potrzebnej nam ilości;

- przekonanie o moźliwości obiektywnego, aksjologicznie neutralnego poznania przyrody;

- przeświadczenie o etycznej neutralności ludzkich działań w przyrodzie, moralnej neutralności techniki i działalności gospodarczej. 
Z tej perspektywy patrząc, ekofilozofią jest poszukiwanie innej niż dotąd, nowej teorii objaśniającej relacje i interakcje czlowieka z przyrodą, tworzenia nowej siatki kategorialnej dla uchwycenia istoty i znaczenia tych zależności i interakcji. Formułowane i prezentowane w obrębie ekofilozofii koncepcje i rozważania koncentrują się najczęściej na:

- dążeniu do zrozumienia i „lokowaniu” przyrody w kontekście (strukturze bytowej) wszystkiego co jakoś istnieje, jej ontologicznej i aksjologicznej charakterystyki $w$ relacji do sfery społecznej i mentalnej (w oparciu o przyjęte założenia ontologiczne i metafizyczne);

- poszukiwaniu takiego pojmowania człowieka, które objaśni go - w każdym wymiarze jego istnienia i funkcjonowania - w jego związkach z przyrodą;

- ocenie wartości i przydatności wiedzy naukowej i innych rodzajów poznania z punktu widzenia możliwości uzyskania życiowo niezbędnej i poznawczo płodnej wiedzy o interakcjach człowieka ze środowiskiem przyrodniczym, wyborze metod osiągania takiej wiedzy i osiąganiu „mądrości ekologicznej";

— tworzeniu nowej „aksjologii ekologicznej”, pojmowaniu wartości ekologicznych i ich hierarchii, systematyzacji itp.

Przynależąc do sfery myślenia teoretycznego ekofilozofia jest zarazem (a może nawet przede wszystkim) filozofią praktyczną (w Arystotelesowym znaczeniu tego określenia). Jest tak, gdyż:

- zmierza do zrozumienia ludzkiego współbycia w przyrodzie - współbycia aktywnie, dziś już w skali globalnej, głęboko i coraz szybciej tą przyrodę zmieniającego - z punktu widzenia skutków ludzkich działań dla dobrostanu człowieka i funkcjonowania biosfery;

- większość kierunków ekofilozofii proponuje i postuluje wdrażanie takich dyrektyw postępowania i działań, które będą respektować mniej czy bardziej radykalną "przyrodocentryczną" hierarchię wartości. Z punktu widzenia „humanistycznego biocentryzmu” zmierza więc do określenia, które działania są dopuszczalne, jakie cele są godziwe, formułuje określone zasady i normy postępowania;

- aspiruje do tego, by być nie tylko intelektualnym poznaniem lecz również czy przede wszystkim - świadectwem współbycia z przyrodą, dziś już w dużej mierze „uczłowieczoną” i przenikniętą duchem. Chce być sztuką życia, a według niektórych - przeżycia;

- postuluje "mądrościowe" ukierunkowanie filozofowania rozumianego jako poszukiwanie mądrości pozwalającej pełniej i lepiej żyć.

I dlatego - jeśli ekofilozofia ma być czymś więcej niż przejściową modą i chce na trwałe wpisać się do rodziny dyscyplin filozoficznych - nie powinna, nie może dać się sprowadzić do tego by być: 
- tylko wyznaniem „zielonej” wiary, niezborną i nieuporządkowaną racjonalnie artykulację emocjonalnie nasyconych "głębokich" przekonań, nową „Dobrą Nowiną";

- ideologią, programem politycznym - choć może stanowić jego teoretyczną podstawę;

- wiedzą o środowisku i jego ochronie czy o humanistycznych aspektach ochrony środowiska;

- tylko etyką środowiskową (ekologiczną) czy szeroko rozumianą bioetyką;

- wyłącznie ekologią humanistyczną czy ekologią człowieka.

Wszelka filozofia jest tworem człowieka, zawsze więc nosi na sobie piętno ludzkiej przynależności do świata, mniej czy bardziej aktywnego uczestnictwa $\mathrm{w}$ jego sprawach i pisana jest z jego wnętrza. Nie inaczej jest $\mathrm{z}$ ekofilozofią, bo choć z nazwy na relacjach ze środowiskiem przyrodniczym się koncentruje, to przecież po to, by poznawszy i zrozumiawszy je znaleźć aksjologiczne podstawy zrozumienia i usensowienia ludzkiego życia. Jedno bądź drugie lub wszystkiego po trochę. Nie rezygnując $\mathrm{z}$ aspiracji badawczych i zdając sobie sprawę z nieuchronności współtworzenia przyrody w trakcie jej poznawania i niemożności wyjścia poza optykę narzuconą nam przez naturę ludzką, programowo kieruje się „troską antropologiczną": wiedza o relacjach z przyrodą, jej „aksjologizacja” są człowiekowi potrzebne by lepiej żyć - czy nawet - by jeszcze czy w ogóle móc żyć. Tym samym ekofilozofia ukazuje swój antropologiczny wymiar - jest jeszcze jedną, współczesną filozofią życia.

\title{
Eco-philosophy and the natural environment
}

\author{
SUMMARY
}

The article contains a semantic analysis of the terms of 'eco-philosophy, and discusses this theme widely as well as dosely presenting the relation between a human being and the natural eivironment. 